\title{
Psychoanalytic Comment on Lee Chang-Dong's Film <Secret Sunshine>
}

\author{
Byung-Wook Lee \\ Hanbit Mind Research Institute, Seoul, Korea
}

\section{이창동의 영화 〈밀양〉에 대한 분석적 논평}

\author{
이 병 욱 \\ 한빛마음연구소
}

Lee Chang-Dong's film $<$ Secret Sunshine $>$ made a sensation in Korea for a while, because it deals with very sensitive religious issues of crime and revenge, salvation and repentance, forgiveness and etc. After losing her husband, a young widow Shin-Ae with her only son relocates to a small-town called Milyang for a new start. That place was her husband's old hometown. But one day her son was suddenly kidnapped and murdered by a familiar neighbor. When tragedy struck, one local man Jong-Chan stood by her through all of her struggles and tried to encourage her. But she was driven to despair, and then had religious help from the church. Furthermore she was persuaded to forgive a murderer in prison. When she met him in prison for the sake of forgiveness, he announced to her that he already was forgiven by God, and he looked very happy and overwhelmed with joyful blessed mind. She was shocked to his comment, and fell down. Just after meeting, she was suddenly changed to a defiant attitude toward Christianity, and began to act-out her revengeful mind. As a result she was admitted to psychiatric hospital, and after discharge she returned to her home with cool mind, but Jong-Chan tried to protect and support her endlessly. He was indeed real secret sunshine to her. This story is very painful and impressive because it is not a story about the others, but ourselves. We can simply diagnose her condition as posttraumatic stress disorder, but do we have really helpful means for her? Indeed we have to admit that there is no single or simple resolution. Above all things, she requires well-timed mourning process, and her self-understanding and self-acceptance just before undeserved forgiveness. Her main defense mechanisms are very primitive and immature, those are denial, projection, splitting, projective identification, primitive idealization, rationalization, acting-out and etc. Besides she reveals many hidden minor faults that were indirectly induced to her son's death, those are as-if quality, lie, self-conceit, vanity and etc. Moreover she was not aware that her religious faith was shallow, and then she had not yet qualified for the forgiveness. After all impatient and forced religious intervention without proper therapeutic approach and mourning process resulted in more aggravated conditions. She needs for a safety zone, persistent concerns and care-taking, empathic understanding and sharing in here and now, and proper self-understandings.

Psychoanalysis 2017;28(1):1-11

KEY WORDS: Milyang · Trauma $\cdot$ Forgiveness $\cdot$ Loss $\cdot$ Mourning.

Received: September 12, 2016 Revised: September 26, 2016 Accepted: October 1, 2016

Address for correspondence: Byung-Wook Lee, MD

Hanbit Mind Research Institute, 316 Banpo-daero, Seocho-gu, Seoul 06509, Korea

Tel: +82-2-536-9775, E-mail: hanvitwooklee@naver.com

\section{서 론 \\ 이창동 감독의 2007년작 영화 〈밀양〉은 제60회 칸 영화제 에서 주연배우인 전도연에게 여우주연상의 영예를 안겨 줌}

This is an Open Access article distributed under the terms of the Creative Commons Attribution Non-Commercial License (http://creativecommons.org/licenses/by-nc/3.0) which permits unrestricted non-commercial use, distribution, and reproduction in any medium, provided the original work is properly cited.
으로써 더욱 유명해졌지만, 국제적인 명성뿐 아니라 이청준 의 소설을 원작으로 했다는 점에서도 주목할 가치는 충분하 다. 왜냐하면 가해자와 피해자, 상실과 애도 및 정신적 상처, 구원과 용서, 화해와 속죄 등 결코 수월치 않은 주제를 다루 고 있기 때문이다. 그러나 이청준의 원작이 보다 어둡고 절 망적인 상황을 보여 준다면, 이창동의 영화는 새로운 사랑과 출발의 가능성을 열어 놓았다는 점에서 일말의 기대와 희망 을 보여 주기도 한다. 
예기치 못한 죄악에 직면했을 때, 선량한 인간은 스스로를 지탱하지 못하고 무너지기 쉽다. 그러한 정신적 붕괴를 막아 주는 가장 중요한 사회적 장치는 물론 종교라 하겠다. 그러 나 종교 역시 나름대로의 한계를 지닐 수 있다. 더욱이 살인 을 저지른 가해자를 용서한다는 문제에 있어서는 경솔하게 종교적 독단에 치우칠 경우, 영화 〈밀양〉에서도 보듯이 가해 자는 구원받고 피해자는 더욱 절망의 나락으로 빠지게 되는 우를 범하게 되는 것이며, 그것은 또 다른 범죄일 뿐 아니라 피해자를 두 번 죽이는 행위가 될 것이다.

죄는 미워해도 사람은 미워하지 말라는 말이 있다. 그러나 이는 매우 이중구속적인 메시지가 아닐 수 없다. 이런 말로 가해자는 득을 보지만 피해자는 아무런 위안도 얻지 못한다. 더욱이 살인일 경우에는 피해자를 더욱 큰 혼란에 빠트리기 일쑤다. 다시 말해 가해자의 논리에 편승하는 말일 뿐이다. 여기서 우리가 마주치는 문제는 바로 악에 직면한 평범한 인 간이 과연 그 악을 어떻게 다루고 대처해 나가야 할 것이냐에 있다고 할 수 있다. 따라서 이 부분에 우리가 그냥 적당히 피 해 갈 수 없는 막다른 딜레마가 있는 것이다. 개인적 차원의 복수와 단죄는 또 다른 악이 될 것이며, 그 반대의 극에 위치 한 용서와 화해는 말처럼 그리 간단치가 않기 때문이다. 영 화 〈밀양〉은 그러한 인간적 모순을 다루고 있다는 점에서 이 는 결코 남의 이야기가 아니다.

\section{본 론}

\section{<밀양>과 <벌레 이야기>}

영화 〈밀양〉의 원작은 이청준이 1985년에 발표한 소설 〈벌 레 이야기>이다. 소설의 제목 자체가 너무 원색적이긴 하나 그 내용은 더욱 처절하다. 무대는 서울이며 주인공은 약국을 운영하는 가정주부다. 그녀의 가족은 남편과 어린 아들 알암 뿐이지만 어느 날 갑자기 아들이 실종된 후 주산학원 지하 창고에서 시체로 발견된다. 졸지에 어린 아들을 잃은 엄마는 이미 제정신이 아니었다. 살인범 김도섭이 잡혔다고 하지만 그렇다고 죽은 아들이 되살아 돌아오는 것도 아니었다. 이웃 여인 김집사의 권유로 기독교신앙에 귀의하여 겨우 안정을 취해 보지만, 김집사는 인간을 마지막으로 심판할 수 있는 일은 오로지 하나님뿐이며, 인간이 할 수 있는 일은 단지 남 을 용서하는 의무밖에 주어지지 않았다고 하면서, 살인범을 찾아가 용서하라고 간곡히 당부한다.

그러나 김집사의 말을 곧이곧대로 믿고 따른 결과 사태는 더욱 악화되고 만다. 힘들게 내린 결단으로 살인범을 용서하 고자 면회를 신청했으나 이미 살인범은 옥중에서 하나님의 용서를 받고 구원을 얻어 그지없이 평온한 마음을 유지하고
있었던 것이다. 자신이 용서할 기회마저 송두리째 빼앗겨 버 린 엄마는 더욱 큰 절망의 나락에 빠져 결국 자살하기에 이 른다는 것이 소설의 줄거리다. 그 과정에서 무기력하기만한 남편은 아무런 도움도 되지 못한다. 단지 아들과 아내의 비 극적인 최후를 무덤덤하게 증언할 뿐이다. 따라서 여기서 남 편의 존재는 살인을 저지르고 구원받은 벌레와는 또 다른 제 3 의 차원에 속하는 무심한 벌레로 등장한다.

이청준은 1980년대 초 서울 영등포구 대림동 우진아파트 에서 벌어진 이윤상 군 유괴살인사건에서 작품 소재를 얻었 다고 하였는데, 당시 이 사건은 매우 큰 사회적 파장을 불러 일으켰으며, 더욱이 살인범이 이윤상 군의 스승인 담당교사 였다는 점에서 그 충격이 더 했다. 그러나 이창동은 당시 발 표된 이 소설을 읽고 우선 광주민주화운동을 떠올렸다고 한 다. 무자비한 살육과 그에 대한 용서 및 화해라는 차원에서 시기적으로도 함께 맞물린 사건이었기 때문이다. 더군다나 당시 광주 청문회로 온 사회가 어수선한 분위기에서는 그의 연상이 오히려 정곡을 찌른 것이었다고 볼 수도 있다.

Lee와 Choi(2002)는 광주 민주화운동의 피해자들이 겪은 정신적 외상에 대한 연구에서, 20년의 세월이 지난 후에도 당시 피해자들의 꿈을 통하여 확인할 수 있는 사실은 특히 분노와 불안의 정서적 장애가 미해결의 상태로 남아 있다는 점을 강조한 바 있다. 물론 그것은 인지적 차원의 용서와 정 서적 차원의 용서가 일치하지 않은 데서 오는 결과일 것이다. 더구나 가해자의 신분이 드러나지 않은 상태에서는 진정한 용서와 화해가 불가능할 것이다.

이청준의 원작 소설 〈벌레 이야기〉는 살인자를 용서한다는 일이 너무도 부담스러워 주인공이 결국에는 자살을 선택하 고 만다는 내용이지만 이와는 달리 이창동의 각본은 희망적 인 결말을 암시하며 끝을 맺는다. 또한 원작에는 아무런 도 움도 되지 못하는 남편이 등장하여 비극적인 사건의 전말을 단조로운 음성으로 증언하는 모습을 보여 준다. 그러나 이창 동 감독은 그러한 설정을 약국 운영에서 피아노 학원을 운영 하는 젊은 미망인으로 각색하고 오히려 약사는 기독교신앙 을 소개한 이웃으로 나온다. 유괴 살해된 아들 알암은 준으 로 바뀌고 살인범은 주산학원 원장 김도섭에서 웅변학원 원 장 박도섭으로 바뀌었다. 무대 자체도 서울에서 밀양으로 옮 겨졌다.

이창동 감독은 〈초록물고기(1997)〉, 〈박하사탕(1999)〉, 〈오 아시스(2002)〉 등의 문제작에 이어 〈밀양〉을 발표함으로써 국내 영화계를 넘어서 국제적인 명성까지 얻으며 자신의 입 지를 확고히 다졌다. 그의 작품에 나오는 주인공들은 한결같 이 자신들이 속한 사회에서 소외된 음지의 인간들이다. 누구 도 그들의 내면에 간직된 아픔과 고통을 공유하거나 이해하 
려 들지 않는다. 인간적인 교류가 단절된 어둡고 비정한 세 계, 그것이 이창동이 증언하고자 하는 주된 화두가 된다. 그 러나 〈밀양〉에서는 신애가 겪는 고통과 아픔에 공감하고 안 타깝게 그녀 주위를 맴돌며 어떻게든 그녀를 지켜주려는 멋 대가리는 없지만 순박한 노총각 종찬이 있어 그런대로 관객 들을 안심시킨다.

다소 살벌한 느낌을 주는 원작 제목을 〈밀양〉으로 바꾼 것은 어두운 음지 가운데 그래도 실낱같은 양지에 대한 희망 을 걸고 살아가는 소시민의 애환을 부각시키기 위한 것이었 는지도 모른다. 밀양은 말뜻 그대로 유난히 햇살이 많은 곳 이다. 그래서 그런지는 몰라도 어둡고 서글픈 한이 많이 담긴 아리랑 민요 가운데 유독 밀양 아리랑만큼은 매우 쾌활하고 흥겨운 가락으로 유명하다. 그러나 이창동은 밀집된 햇살을 의미하는 〈밀양〉의 영어 제목을 비밀스런 햇살(Secret Sunshine)로 부쳤는데, 그것은 영화의 주제를 암시하기 위한 것 으로도 보인다. 왜냐하면 햇살 한 줄기에도 하나님의 은총이 배어 있다는 약국 여집사의 주장에 반박하는 신애의 말에서 그러한 논쟁의 핵심을 엿볼 수 있기 때문이다. 신애는 햇살 은 단지 한줄기 빛에 불과할 뿐이라고 강하게 반발한다. 그 러나 마지막 장면에 마당 한구석을 비추는 따스한 햇살은 일 종의 타협점을 찾아가는 신애의 마음상태를 암시한다. 그런 점에서 〈밀양〉을 단순한 기독교 비판 영화로 볼 수도 없다.

영화 〈밀양〉의 줄거리는 다음과 같다. 남편을 잃은 젊은 과부 신애는 어린 아들을 데리고 남편의 고향인 밀양을 찾 아 그곳에 정착하고 새로운 삶을 시작한다. 그러나 예기치 못한 유괴 살인사건으로 아들을 잃고 극도의 절망감에 빠진 다. 그녀는 우연히 기독교의 복음을 접하고 교회에 나가 하 나님을 받아들이며 마음의 평안을 얻으면서 아들의 살해범 을 용서하기로 결심하게 된다. 그녀는 같은 신도들의 성원에 힘입어 크게 용기를 내고 교도소에 복역 중인 살해범을 찾 아가서 하나님의 용서를 전하고자 한다.

그런데 뜻밖에도 살해범은 자신도 감옥에서 복음을 듣고 하나님의 용서를 이미 받았으며, 따라서 이제는 자기 마음도 평안하기 그지없어 눈뜰 때나 잠들 때나 오로지 하나님의 축 복에 감사하는 마음으로 하루하루를 지낸다는 것이다. 신애 는 이 말을 듣고 망연자실한다. 용서의 주체로서 그녀의 위 치가 일시에 사라져 버렸기 때문이다. 그녀는 용서란 피해자 인 자신이 하는 것이 마땅한 일임에도 하나님이 자기보다 먼 저 용서해 주었다는 사실에 큰 충격을 받는다. 인간으로서 도저히 저지를 수 없는 악행의 당사자가 뼈아픈 후회와 죄의 식으로 괴로워하는 것이 아니라 오히려 아무런 자책과 고통 없이 자신의 모든 죄를 용서받았기에 매일의 일과가 즐겁고 평온하다는 것은 그녀에게 또 다른 충격을 주었다. 결국 가
해자는 구원받고 피해자는 더욱 큰 절망의 나락에 빠져든다.

신애는 교회에 대한 반감으로 집사를 유혹하고 가게의 물 건을 훔치며 기도집회를 향해 돌을 던지거나 엉뚱한 노래를 틀어 분풀이를 하기도 한다. 열성적인 기도집회에 몰래 들어 간 그녀는 김추자의 '거짓말이야'를 틀어 기도회를 엉망으로 만들어 놓는다. 결국 신애는 정신병원에서 치료를 받은 후 퇴 원하여 겨우 일상생활로 돌아온다. 비록 그녀의 얼어붙은 마 음이 아직까지는 예전처럼 웃음을 되찾지는 못했지만 그래 도 자기 집 마당에 앉아 차분한 모습으로 자신의 머리를 다듬 는다. 그리고 엉거주춤 그녀의 앞에서 거울을 들고 서 있는 종 찬의 존재를 애써 거부하지 않는다. 바람에 흔들리며 떨어진 그녀의 머리카락 뭉치 위로 따스한 햇살이 내리쪼인다. 그 햇 살에 과연 하나님의 숨결이 배어 있는지 아닌지 여부는 그녀 의 삶에 그리 중요한 문제가 아닐지도 모른다. 그녀에게 가장 소중한 존재는 절망의 나락에 빠져든 순간에도 끝까지 자신 을 곁에서 지켜주고 위로하며 보살펴 주는 살아있는 존재, 비 록 속물적이기는 하지만 그래도 자신에게 따스한 정을 비쳐 주는 노총각 종찬의 너무도 인간적인 햇살일 것이다.

\section{상실과 외상, 그리고 애도}

주인공 신애는 삼중고의 상실로 상처를 입는다. 남편의 죽 음, 아들의 실종과 살해, 피아니스트에 대한 꿈의 상실. 모든 희망을 아들에게 걸었던 신애가 아들의 시신을 확인하러 비 탈길을 비틀거리며 내려가는 뒷모습은 실로 참담하기까지 하다. 게다가 아이의 장례식에서 시어머니는 집안 남자들을 모조리 말아먹는 못된 여자로 그녀를 매도하고 비난한다. 종 찬이 나서서 항의하지만 제3자가 나설 일이 아니라는 이유 로 무시를 당한다. 자식을 잃은 어미의 심정에 공감을 느낄 수 있는 사람은 어디에도 보이지 않는다. 비록 공감을 느낄 수 없어 답답하긴 하지만 그녀에 대한 동정심 내지 측은지 심으로 묵묵히 그녀의 곁에서 애꽃은 담배만 피우며 앉아 있는 카센터 사장 종찬의 모습이 오히려 인간적이다.

마지막 장면에서 신애가 거울을 보며 자신의 머리를 자르 려 할 때, 종찬이 나타나 다소 엉거주춤한 자세로 대신 거울 을 들어주는 모습은 그나마 미래의 가능성을 보여 준다. 그리 고 두 남녀에서 이동한 카메라는 초라한 마당 한구석에 내리 쪼이는 햇살에 시선을 잠시 고정시킨 채 마지막 엔딩 자막이 오른다. 종찬의 따뜻한 마음에 문을 연 신애의 모습을 상징 하는 장면이다. 밀양은 그래서 신애에게는 말로만 햇빛 가득 한 도시일 뿐 실제로는 잔인한 도시라는 오명에서 벗어나 정 으로 가득 찬 도시로 거듭날 수 있는 여지를 암시한다.

Freud(1917)는 애도와 우울증을 구분하고, 애도는 외부 대 상의 상실에 대한 반응이지만, 우울은 징벌과 관련되어 나타 
나는 것으로 그것은 내재화된 대상과의 관계 측면에서 이해 할 수 있다고 하였다. 여기서 프로이트는 내적 대상과 외부 대상에 대한 개념을 분명이 언급하고 있다. 그러나 신애의 경우는 비록 외부 대상인 아들의 죽음에 대한 애도를 보이 고는 있으나 그녀 자신의 내면에 간직된 대상으로서의 아들 과 남편에 대한 관계는 분명하게 드러나지 않는다. 물론 내 적 대상에 대한 부정적인 감정은 그녀의 내면에 억압되어 있음에 틀림없겠지만, 그녀에게는 그런 복잡한 감정들에 대 한 해소의 기회가 주어지지 않았던 것이 더욱 큰 불행을 초 래한 것으로 보인다.

그런 점에서 Kubler-Ross(1969)가 말한 죽음의 5단계는 임종 환자뿐 아니라 죽음을 지켜보는 가족들에게도 적용할 수 있는 문제라고 본다. 예기치 못한 비극적인 죽음일 경우 에는 더욱 그렇다. 그녀가 말한 5 단계란 부정과 격리, 분노, 협상, 우울, 수용의 순서로 진행되는 것으로 죽음을 맞이하 는 사람에게서 보편적으로 일어날 수 있는 현상이라 할 수 있겠지만, 신애의 경우는 좀 다르다. 아들의 유괴에서부터 죽음에 이르기까지 신애가 보인 심리적 과정을 보면, 오히려 구출과 협상, 부정과 격리, 우울, 구원과 용서, 좌절과 분노, 재협상, 수용의 순서로 진행되었음을 알 수 있다. 그녀가 정 상적인 단계를 거치지 못한 이유는 물론 상황의 특수성 때문 일 것이다. 그것은 극적 반전을 이루는 사건의 특수성 때문 이기도 하다. 아들의 실종과 살해, 종교적 구원과 용서라는 문제가 그러한 반전의 축을 이루고 있기 때문이다.

Bowlby(1961)는 어머니의 상실에 대한 유아의 애도반응 과정을 세 단계로 구분하였는데, 그것은 반항(protest), 낙담 (despair), 이탈(detachment)의 순서로 진행된다는 것이다. 그러나 아들의 상실에 대한 신애의 애도반응은 낙담, 반항, 이탈의 순서로 진행된다. 보다 구체적으로 말하자면, 아들의 유괴살인 직후 신애는 절망적인 혼란상태에 빠지지만, 자신 의 구원을 확인받기 위한 용서의 기회가 실패로 돌아가자 종교 및 세상 전체에 대한 반항으로 돌변한다. 그리고 사회 에서 이탈된 상태로 정신병원을 거쳐 간신히 집으로 돌아오 지만 완전히 회복된 상태는 아니다.

정신과적 진단에서 외상후 스트레스 장애는 단순한 신경 증의 단계를 넘어 거의 정신병적 수준에 버금갈 정도로 사회 적응에 어려움을 보인다. 그것은 물론 평범한 일상생활에서 는 겪기 어려운 매우 예외적인 정신적 충격에 의한 것이다. 신애가 겪은 아들의 참혹한 죽음은 당연히 이러한 예외적 사 건에 속한다. 남편의 죽음도 물론 그녀에게는 충격을 주었겠 지만 끔찍스런 아들의 죽음에는 견줄 수 없는 일이었을 것이 다. 그러나 사랑하는 가족의 연이은 죽음은 그녀의 아픔을 배가시켰을 것임에 틀림없다.
Bose(1995)는 그동안 정신분석 분야에서 정신적 외상에 대한 관심이 상대적으로 소홀했던 것이 사실이지만, 최근에 이르러 다시 재조명되고 있음을 말하고, 외상적 충격으로 인 한 우울과 상실 및 애도과정의 어려움뿐 아니라 감당할 수 없는 외상적 경험에 대한 해리적 반응 또한 중요하게 다루어 져야 할 부분이라는 점을 강조하였다. 이는 실제로 많은 외 상후 스트레스 장애 환자들에서 공통적으로 발견할 수 있는 정신병리 현상 가운데 하나라고 할 수 있다. 아들을 잃고 난 신애가 다른 아이들을 자신의 아들로 착각하는 모습이나 교 도소에서 살해범과의 면회를 마치고 나오자마자 의식을 잃 고 쓰러지는 모습도 일종의 해리현상의 일부인 셈이다.

Pollock(1975)은 그 자신의 애도경험을 토대로 많은 환자 들을 분석한 결과, 이러한 애도과정이 인간의 적응활동에 필 수적인 요인임을 발견하였으며, 그 뿌리는 조기 발달경험에 두고 있다고 주장하였다. 그리고 성인기에 겪는 네 가지 상실 로 부모의 죽음, 형제의 죽음, 배우자의 죽음, 자식의 죽음 등을 들었다. $\operatorname{Kim}(2005)$ 역시 애도의 과정이 상실한 대상과 의 관계 정리일 뿐 아니라 새로운 적응으로 가는 필수적 단 계라고 하였다. 그것은 결국 사랑하는 사람을 영원히 먼 곳으 로 떠나보내는 일에 해당되지만, 그 애정관계의 정리는 말처 럼 그렇게 용이한 일이 아니며, 평소의 내적 대상과의 관계 특성에 따라 그 해결방식이 좌우되기 쉽다. Burch(1989)는 조기 발달단계가 단순한 획득과정으로만 볼 수 없으며, 얻는 것 못지않게 잃는 것도 많다는 점에서 지속적인 상실의 과정 으로 간주할 수도 있다고 하였다. 그리고 이러한 상실을 적 절히 다루고 극복할 수 있는 아동의 능력은 향후 발달에 근 본적인 결정요인으로 작용한다는 것이다.

물론 신애가 남편의 고향 밀양을 찾아 그곳에 정착한 것 도 일종의 애도반응 과정의 일부로 볼 수 있다. Wolfenstein (1969)에 의하면, 부모 상실을 경험한 아이들의 경우 부모가 언젠가는 자기 곁으로 다시 돌아올 것이라는 환상과 영원히 돌아올 수 없는 죽음의 세계로 갔다는 사실을 인정하는 두 가지 모순된 경향이 함께 공존한다고 하면서 그런 자아의 분리상태가 다른 대인관계를 포함한 세상과의 관계에서도 확장되어 나타날 수 있다는 것이다. 그러나 신애가 선택한 도시는 남편 대신 종찬을 선사했지만 소중한 아들을 빼앗아 가고 말았다. 더욱이 아들에 대한 애도과정은 느닷없이 용서 를 강요한 종교의 개입으로 인해 오히려 뒤죽박죽이 되었던 것이다. 살해범에 대한 용서와 화해는 충분한 애도과정을 겪 지 못한 상태에서 오히려 성급한 신앙적 과욕이 부른 부작용 만 낳고 말았다. 일개 나약한 아녀자에 불과한 신애에게는 실로 소화시키기 어려운 주문이었던 셈이다. 그런 점에서 종 교는 더욱 겸허하게 자신의 몸을 낮추고 상처입은 인간에게 
다가서야 할 것이다. 따뜻한 위로와 고통의 공유만으로도 신 애는 마음의 상처를 극복할 수 있었을지도 모른다. 차라리 우직스런 종찬에게 충분한 시간적 여유를 갖고 모든 임무를 위임했더라면 그 편이 더욱 나았을 것이다. 종교는 비록 신 애의 참담하고도 절망적인 심리적 위기에 개입하여 일시적 인 안정을 주었지만, 좀 더 많은 시간적 여유를 두면서 보다 깊은 승화 및 변화의 기회를 주지 않고 성급하게 무리한 요 구를 가함으로써 오히려 그녀의 적절한 애도과정을 방해하 고 그 맥을 끊어 놓는 결과를 낳고 말았다. 따라서 처음부터 신애에게 적절한 목회상담 또는 정신과적 치료가 병행되지 못한 것이 그녀를 더욱 큰 혼란과 파국으로 몰고 가는 결과 를 낳은 셈이 되었던 것이다.

\section{죄와 벌}

밀양이 어떤 곳이냐는 신애의 질문에 종찬의 대답은 사람 사는 곳은 다 비슷하다고 말한다. 그렇다. 사람이 사는 세상 은 어디나 다 비슷하다. 운 좋게도 좋은 사람들을 만나 웃고 떠들며 살아갈 수 있으면 그나마 다행이다. 그러나 인간의 삶에는 항상 좋은 일만 있을 수 없다. 전혀 예기치 못한 불운 이 따르기도 한다. 많은 사람들이 모여 사는 집단에는 온갖 다양한 인격체들 간에 벌어지는 크고 작은 갈등들이 존재하 기 마련이다. 그리고 그 안에서 죄악도 발생한다. 고립된 삶 에서는 죄악이 벌어질 여지가 없다. 그러나 인간은 외로움과 소외감 때문에 인간적 교류를 원한다. 신애는 자신에게 호의 적으로 접근하는 종찬을 오히려 경계했지만 정작 위험한 학 원원장에게는 그 어떤 경계심도 두지 않았다. 아들을 맡기고 있었기 때문이다. 그러나 믿었던 사람에게서 악을 발견할 때 처럼 인간을 절망에 빠트리는 일도 없을 것이다.

물론 인간은 누구나 크고 작은 허물과 실수, 죄를 범하고 살지만, 유괴와 살인은 천륜을 파괴하는 가장 극악무도한 범 죄다. 왜 하필이면 내게 이런 일이 벌어지는가? 이에 대한 해 답은 그 누구도 할 수 없다. 기독교는 원죄를 말하고, 불교는 전생의 업보를 말하지만, 그것으로 충분한 답이 될 수 없다. 정신분석 또한 적절한 해답을 제시할 수 없다. 중요한 것은 고통에 동참하고 공유하는 일이다. 물론 법은 죄인을 체포하 고 구속하며 벌을 가하지만, 그런다고 해서 신애의 마음이 위로받는 것은 아니다. 이 세상에는 죄악을 저지르는 사람과 벌하는 사람이 있으며, 세인들은 이들에게 많은 관심을 기울 이지만, 정작 그 희생자에 대한 관심과 대책은 거의 존재하 지 않는다. 그나마 종교가 이들에게는 큰 의지처가 된다. 그 러나 죄의 심판과 용서에 대해 종교는 스스로의 본분을 지 켜야 마땅할 것이다.

악행을 저지른 죄인에 대한 인간의 법적 심판이 하나님의
일방적인 개입으로 한순간에 용서받고 무효화된다면 인간의 악행은 실로 근절되기 어려울 것이다. 세속법이 존재하는 이 유는 물론 사회질서와 기강을 바로 잡는 것이 목적이다. 동 시에 죄인으로 하여금 자신의 죄를 깨닫고 개심하여 재범을 예방함으로써 또 다른 피해자가 나오지 않도록 하기 위함이 다. 죄질에 따라서는 극형에도 처한다. 뉘우침이 없을 경우 에는 영원히 사회로부터 격리도 시킨다. 그러나 여기에 하나 님의 법이 개입하여 피해자나 법 집행자의 동의도 구하지 않 고 일방적으로 용서를 해 버리면 간교한 자들은 어차피 용서 받을 일이기 때문에 자신의 죄악을 멈추지 않을 수도 있다. 죄악과 회개, 용서의 악순환이 반복될 뿐이다. 밑져야 본전 이니 일단 용서해 보고 안 되면 말고 하는 식으로 무사안일하 게 대처할 일이 결코 아닌 것이다.

선행의 실천보다 더욱 어려운 일은 악의 근절이다. 인간은 누구나 크고 작은 악을 행한다.

따라서 타고난 선인 또는 악인이 따로 존재하는가에 대한 논의는 오늘날의 유전학적 관점을 떠나 오래 전부터 매우 심각한 논쟁의 중심이 되어온 것이 사실이다. 물론 불교에서 는 타고난 불성을 말하고, 기독교에서는 타고난 원죄를 말한 다. 맹자는 성선설을 주장했고, 순자는 성악설을 내세웠다. 그러나 이처럼 첨예하게 대립된 논쟁은 정신분석적 이해로 모두 수렴될 수 있는 문제라 할 수 있다. 비록 프로이트가 인 간의 본성으로 간주했던 성과 공격성 자체는 오랜 기간 대 부분의 사회에서 악으로 규정되어 온 것이 사실이지만, 프로 이트는 그것을 선악의 구분이라는 도덕적 관점에서 이해한 것은 물론 아니다.

그런 점에서 Alford(1997)는 악의 실체에 대하여 온갖 다 양한 형태의 육체적, 정신적 폭력을 동원하여 타인의 심신 내부에 존재하는 궁극적인 현실과 접촉하여 두려움 없이 만 족을 얻으려는 시도로 보고, 그러나 인간은 누구나 악을 경 험하지 않고 살아갈 수 없음을 강조했다. 그는 "악(evil)을 거 꾸로 읽으면 삶(live)"이라고 하면서, 악은 특히 실제보다는 이론적인 면에서 매력적이기 때문에 흡혈귀나 사탄이 매력 적으로 보이기도 하지만, 그러나 실제로 악을 접하게 되면 누 구나 심리적 혼돈 상태에 빠지기 쉽다고 하였다.

Zimbardo(2007)는 평범한 일반인도 얼마든지 상황에 따 라서는 악인이 될 수 있음을 실험을 통하여 입증하고 그것 을 루시퍼 효과라고 불렀다. 루시퍼는 원래 신의 총애를 받 았던 천사였지만 그 후 사탄이 되어 신의 권위에 도전하는 악마로 변신했기 때문이다. 그가 내린 결론에 의하면, 썩은 사과 한 개가 문제를 일으키는 것이 아니라 썩은 상자 자체가 문제라는 것이다. 또한 악행에 대하여 이의를 제기하거나 제 지시키지 않고 수수방관하며 아무런 행동도 하지 않는 방관 
자 역시 악이라는 주장이다. 물론 이러한 주장은 죄인에게 면죄부를 주려는 의도에서가 아니라 인간을 악으로 내몰 수 있는 상황에 단호하게 대응할 수 있는 힘을 키워야겠다는 동 기에서 나온 말이다. 그러나 자칫 이러한 주장이 잘못 일반 화되어 인용된다면 악행에 대한 책임 소재가 불분명해질 수 있는 허점이 있다.

반면에 사회심리학자 Miller(2005)는 보다 낙관적인 견해 를 드러낸다. 왜냐하면 인간의 이기적이고도 악한 본성뿐 아 니라 이타적이면서 열정적인 본성 또한 인정하기 때문이다. 다만 그가 강조하는 바는 이런 문제에 대하여 종교의 기능은 이미 그 한계를 보이고 있기 때문에 선악을 분별할 수 있는 교육을 이른 나이부터 시행해야 한다는 것이다. 그러나 단지 교육만으로 고질적인 인간 본성의 문제를 해결할 수 있다고 믿는 것은 매우 순진한 발상으로 보인다. 물론 역기능적인 측 면도 있는 것이 사실이지만 종교가 지니는 순기능적 측면도 결코 무시할 수 없기 때문이다. 그런 점에서 종교에서 말하는 영원한 삶을 보장하는 불멸의 상징은 새로운 유형의 불안정 과 불안을 가져왔으며, 악을 회피하기 위해 인간은 오히려 더욱 많은 악을 이 세상에 가져왔다는 Becker(1985)의 주장 은 지나친 단순화로 보이기도 하지만, 한편으로는 일리가 있 는 말이기도 하다. 마귀를 물리친다는 명분으로 악마적인 행 위를 서슴지 않는 경우도 많기 때문이다. 우리는 중세의 마 녀재판에서 그 전형적인 사례들을 얼마든지 찾아볼 수 있다.

Berke(1996)는 합리성을 초월하는 증오심의 본질에 대한 논의에서, 모든 파괴적인 공격성의 뿌리는 매우 근원적인 심 층세계에 내재된 분노, 혼란, 원한, 사악함 등에 연유하는 것 이며, 기독교에서 말하는 7대 죄악 가운데 특히 선망과 질 투, 탐욕 등 세 가지의 악은 일상생활에서도 흔히 마주치는 속 성들이라고 하였다. 이는 과거 우리나라 유교적 도덕관에서 가장 악명이 자자했던 칠거지악 가운데 질투심이 포함된 사 실을 보더라도 선망과 질투에서 비롯된 문제들이 온갖 분란 을 초래했음을 반영하는 것이다. 신애의 아들 준을 유괴하고 살해한 범인도 실은 일개 속물적인 홀아비 학원 원장에 불과 했지만, 돈에 대한 탐욕뿐 아니라 말썽만 피우고 속을 썩이 는 자신의 딸자식 대신 귀여운 아들을 둔 신애에 대한 질투 심도 작용했을 것이다. Baumeister(1999)는 악의 네 가지 뿌 리에 대하여 탐욕, 이기심, 이상주의, 사디즘 등을 들었다. 그러 나 그는 자존심의 저하가 폭력과 공격성을 야기한다는 일반 론에는 동의할 수 없다고 하였다. 왜냐하면 많은 경우에서 오 히려 자신들의 행위에 대하여 강한 자부심을 지니고 있음을 발견했기 때문이다. 다만 그들의 강한 자존심도 그 어떤 확신 이 없을 경우에는 특히 폭력적으로 변하기 쉽다고 하였다.

이 세상을 죄악의 관점에서 보자면 죄악을 저지르는 가해
자와 그에게서 상처를 입는 피해자로 크게 양분할 수 있다. 그러나 예수는 원수를 사랑하라고 요구하고, 부처는 마귀도 불성이 있다고 설파한다. 물론 가해자는 이런 메시지에 크게 용기를 얻는다. 그러나 피해자는 어떠한가. 더욱 큰 혼란과 좌절에 빠지기 쉽다. 왜냐하면 가해자는 혼란을 느끼지 못하 지만 피해자는 이미 심리적인 평형이 깨진 상태에 있기 때 문이다. 피해자의 입장에서는 원수를 사랑하고 싶어도 그것 이 뜻대로 안되며, 마귀의 불성을 믿고 싶어도 받아들이기 어 렵다. 인간이면 누구나 다 그렇다. 용서할 기회를 빼앗기고 좌절에 빠진 신애가 하나님과 그 교회에 분노의 화살을 돌린 것은 어쩌면 당연한 결과일지도 모른다. 그녀 자신이 가해자 로 돌변한 것이다.

Grand(2000)는 악이 어떤 경로를 통하여 재생산되는지 그 과정을 밝히는 작업에서 피해자가 가해자로 변모하는 데에 는 그가 속한 가정과 문화가 조장시키는 측면도 결코 무시할 수 없다고 하였다. 신애의 거칠고 난폭한 변화도 주위에서 부추기고 조장시킨 결과다. 그녀는 선과 악 사이에서 무엇이 옳고 그른지 갈피를 잡지 못하고 혼란을 경험한 것이다. 물 론 Taylor(1999)가 말하듯이 이 세상에 옳고 그른 것을 입증 할 수 있는 객관적인 기준은 애당초 존재하지 않을 수도 있 다. 그러나 그것이 단지 사회적 관습에 기초한 것이라 할지 라도 도덕적 기준은 필요 불가결한 것이다. 인간은 누구나 비합리적인 측면을 지니고 살 수밖에 없지만 상식적으로 이 해할 수 없는 끔찍스런 악행에 직면한 사람에게 그런 말을 한다면 돌아오는 것은 따귀밖에 없을 것이 뻔하다. 철학자 Buber(1980) 역시 선악의 본질에 대한 논의에서 옳고 그름 의 판정은 서로 다른 관점에서 비롯된 해석일 뿐이라고 하면 서도 그렇다고 해서 선과 악이 동일하다는 것은 결코 아니 며, 그것은 단지 옳고 그름에 대한 인간의 판단에 상대적인 가치가 개입될 여지가 많음을 강조한 것이라고 하였다.

선은 결코 악을 심판하지 못한다. 오로지 용서할 뿐이다. 그것은 하나님만이 할 수 있는 능력이다. 인간은 감히 그러 한 능력을 모방해 보려 하지만 뜻대로 안 되는 것이 인지상 정이다. 불완전한 인간이 하나님의 위치를 넘보는 것 자체가 사탄적 행위라 할 수 있다. 왜냐하면 용서하고 싶어도 용서 가 안 되는 것이 오히려 인간적인 모습이기 때문이다. 인간 의 나약함을 인정하고 하나님에게 모든 것을 의탁할 때, 그 리고 마음속으로 악을 용서하고 자신의 교만함을 회개할 때, 비로소 진정한 구원이 있는 것이 아니겠는가. 신애의 실수는 자신이 직접 살해범을 만나 용서한다는 것이었는데, 그러한 장면은 남들이 보기에 감명 깊은 것일 뿐이지, 정작 본인들 에게는 아무런 도움도 될 수 없는 행위라 하겠다. 물론 하나 님의 대행자인 성직자들은 죄인을 용서할 권한이 주어지지 
만, 신애 자신이 나서서 죄인을 용서하겠다고 한 일은 오히 려 교만에 가깝다. 진심에서 우러난 것이 아닐 때 보이는 극 적인 용서는 일종의 반동형성이기 쉽기 때문이다. 다시 말해 서 마음속 깊은 곳에 숨겨진 살인자에 대한 복수심과 분노 를 대신해 그에 정반대되는 자애로움이 의식 표면에 나타나 는 것이다. 그것은 동물학대 욕구를 대신하여 겉으로는 동물 보호운동에 헌신하는 태도로 나타나는 것과 비슷하다.

세상인심은 실로 기묘하기 그지없다. 끔찍스런 사건이 벌 어지면 세상의 모든 관심은 가해자에게만 집중되기 마련이 다. 그리고 하는 말은 세상 살기가 두렵다는 것이다. 가해자 를 비난하고 엄벌에 처할 것을 요구하는가 하면, 반대로 죄는 미워하되 사람은 미워하지 말자며 용서하고 선처를 빌기도 한다. 심지어는 사형 집행을 기다리는 죄수를 찾아가 회개시 키고 용서와 구원을 얻게 하기도 한다. 그러나 이처럼 지대한 관심을 기울이는 가해자와는 달리 피해자의 가족들에 대한 관심은 좀처럼 찾아보기 어렵다. 어떤 점에서는 사회복지 차 원에서 피해자 가족에 대한 정신적 문제 해결에 도움을 줄 수 있는 제도적 장치가 필요할지도 모른다. Lee(2005)는 반사회 적 성향이 자연스럽게 사회의 일부로 수용되는 과정에 대해 우려를 표명하면서 마치 그것이 불의에 항거하는 의협심의 발로인 듯이 착각함으로써 사회 전반에 일반화될 수 있는 가능성을 지적하고 그러한 사회의 특성을 반사회적 사회라 고 불렀다. 우리는 실제로 국가체제라는 명분하에 그러한 병 리적 특성들이 정당화되고 적극 권장되곤 했던 전체주의사 회를 경험한 바 있다.

\section{용서와 화해}

악행에 희생당한 피해자 가족에게 그 악인을 용서하고 화 해하라는 요구는 그 누구도 감히 할 수 없는 월권행위요 만 용에 속한다. 비록 예수는 원수를 사랑하라고 하셨고 석가모 니는 자비의 실천을 요구하셨지만 그것은 속세를 초월한 성 자들에게나 가능한 일이다. 자신의 가족을 살해한 악인을 진 심으로 용서하고 그의 영적 구원을 위해 기도하는 사람들이 있다면 그들은 이미 성자의 반열에 오를 사람들이다. 그러나 깨달음의 수준에 이르지도 못했으면서 성인을 모방하여 그 러한 행위를 실천하는 사람이 있다면 그는 자기 자신을 속이 고 기만하는 것이거나 아니면 알암의 아빠처럼 몹시 무신경 한 사람일 것이다. 살인자를 이해하고 용서를 해주기로 마음 먹은 알암의 엄마가 스스로 무너진 것은 그러한 자기 기만성 에 직면하고 더 이상 자신을 속일 여력을 상실했기 때문이다. 그런 점에서 그녀가 외친 말은 매우 솔직한 심경의 고백이다. "그래요. 내가 그 사람을 용서할 수 없었던 것은 그것이 싫 어서보다는 이미 내가 그러고 싶어도 그럴 수가 없게 된 때
문이었어요. 그 사람은 이미 용서를 받고 있었어요. 나는 새 삼스레 그를 용서할 수도 없었고, 그럴 필요도 없었지요. 하 지만 나보다 누가 먼저 용서합니까. 내가 그를 아직 용서하 지 않았는데 어느 누가 나 먼저 그를 용서하느냔 말이에요. 그의 죄가 나밖에 누구에게서 먼저 용서될 수가 있어요? 그 럴 권리는 주님에게도 있을 수가 없어요. 그런데 주님께선 내게서 그걸 빼앗아 가버리신 거예요. 나는 주님에게 그를 용서할 기회마저 빼앗기고 만 거란 말이에요. 내가 어떻게 다시 그를 용서합니까(Yi 1985)."

맞는 말이다. 누가 감히 그녀를 대신해서 제멋대로 가해자 를 용서하고 말고 한다는 것인가. 적어도 그를 회개시키고 용서를 시킬 의향이 있었던 성직자라면 우선 피해자 가족들 에게 동의를 구했어야 했다. 그 정도의 경우와 예의조차 지 니지 못한 성직자라면 성직자로서의 자격이 없는 것이다. 광 주 청문회에 출석한 어느 피해자가 했던 말도 같은 맥락에 서 이해할 수 있는 내용이다. 가해자가 누군지도 모르는데 과연 누구를 상대로 용서하고 화해한다는 말인가. 일제 당시 정신대 문제도 마찬가지다. 용서를 하고 싶어도 그 누구도 나서서 자신의 죄를 인정하고 참회하는 사람이 없는데 과연 진정한 화해와 용서가 가능할 것인가. 그러나 종교에서는 그 것이 가능하다고 주장하며 실천에 옮길 것을 요구한다. 물론 추상적인 차원에서는 얼마든지 가능할지도 모른다. 다만 고 통스런 감정문제를 배제한 관념적 용서는 아무런 의미도 없 을 뿐 아니라 자칫하면 위선에 빠질 위험이 있다. 그런 점에 서 Kris(2005)는 위선이란 의식적으로 의도된 기만행위로서 선과 미덕을 가장한 것으로 보면서, 그러나 위선으로 이끄는 전제조건 가운데 하나인 이상화는 불확실성의 두려움에 대 한 방어로 작용한다는 것이다. 신애의 정서적 혼란과 불확실 성에 대한 두려움은 풀 한 포기라도 잡는 심정으로 교회에 매달리지만, 용서라는 감당하기 어려운 위선적 요구에 순진 하게 따름으로써 자신을 이상화시키는 데 실패하고 만다. 그 녀의 작고 초라한 그릇은 그토록 큰 요구를 담을만한 공간 이 없었던 것이다. 용서란 아무나 하는 일이 아니기 때문이 다. 물론 말로는 얼마든지 할 수 있겠지만 진심어린 용서란 그처럼 손쉬운 일이 아니다.

그런 점에서 유명한 정신과의사 Peck(1983)이 권하는 충 고는 현실적으로 매우 유익한 도움이 될 수 있다. 그는 자신 의 이익을 추구하기 위해 타인을 희생시키는 것 자체를 악 으로 규정하고, 사악한 인간은 자신이 항상 선량하게 보이기 를 원하기 때문에 항상 거짓을 동원하여 자신의 저의를 숨기 기 마련이며, 따라서 악의 핵심인 자기중심적인 인간은 신을 두려워하는 선량하고 건전한 시민의 이미지로 자신을 위장 함으로써 자기 스스로를 기만하는 데도 능숙하다고 하였다. 
또한 악에 직면할 경우, 가장 현명함을 자처하는 사람도 혼 란을 겪기 마련이며, 그런 점에서 악은 타인의 의존성을 조 장시킴으로써 스스로 생각할 수 있는 용기마저 꺾어버린다 고 하였다. 이러한 악의 특성 때문에 그는 악에 대적하기 위 해서는 무슨 수를 써서라도 자신의 일상적인 현실에 충실해 야 할 것임을 강조한다.

그러나 신애는 그러한 일상에서 벗어나고 말았던 것이다. 그녀는 어설픈 복수와 용서 사이에서 오히려 자신의 중심을 놓아버린 결과를 초래하고 만 것이다. 따라서 그녀는 적절한 애도의 기회와 진정한 참회 및 용서와 화해, 구원 등 모든 기 회를 잃고 말았다. Lansky(2005)는 유리피데스의 비극 〈메 데아>를 중심으로 나르시시즘적 붕괴로 인하여 통렬한 치욕 감이 어떻게 악마적인 복수심으로 변모되어 가는지 그 과정 을 규명하고 있는데, 이처럼 용서를 용납하지 않는 심리적 배경에는 편집증적 수치심, 수치심의 투사적 동일시, 그리고 수치심에 대한 방어로서의 위축 등이 작용한다고 하였다. 그 러나 신애의 경우는 수치심 때문이라기보다는 사랑과 미움 의 통합에 실패한 그녀 자신의 내면적 혼란에 더욱 큰 문제 가 있는 것으로 보인다. 모든 종교는 사랑과 자비심만을 강 조하지만 그에 못지않게 각자의 내면에 잠재된 미움과 공격 성을 도외시한 채 사랑과 화해의 실천은 말처럼 그렇게 손 쉬운 일이 아닐 것이다.

Freud(1920) 역시 초기이론에서는 사랑에 준하는 리비도 만을 강조했으나, 후기이론으로 가면서 공격성에 중점을 두 면서 미움을 결코 과소평가할 수 없음을 알게 되었다. 에로 스와 타나토스 이론은 그 최종적 결론이기도 했지만, 그렇다 고 해서 문제가 해결된 것은 아니었다. 결국 조기 모자관계 에서 가장 중요하게 다루어지는 사랑과 미움의 통합문제는 대상관계이론에 의해 보강되었다. 그런 점에서 엄마 품에 안 겨 젖을 빨 때부터 이미 유아의 파괴적 욕구와 환상이 존재 한다는 사실을 규명한 Klein(1964)의 주장은 매우 충격적이 기까지 하다. 더 나아가 그녀는 프로이트의 남근 선망 이전 에 선행되어 나타나는 유방 선망을 강조함으로써 공격성과 결부된 선망의 중요성을 더욱 부각시켰을 뿐만 아니라 생의 초기 편집성 입장에서 우울 입장에 도달하는 과정을 통해 원초적 감정과 방어기제의 발전단계에 대해서도 소상히 밝 힌 바 있다(Klein 1964). 이처럼 유아적 단계를 벗어나 본격 적인 성숙의 길로 접어들게 될 때 비로소 인간은 감사할 줄 아는 마음을 지니게 된다는 것이 Klein(1975)의 주장이기도 하다. 그런 점에서 신애가 진정으로 용서하고 화해하며 감사 하는 마음상태에 도달하기 위해서는 그녀 자신의 유아적 수 준에 머문 사랑과 미움의 부조화 상태에서 벗어나 보다 성숙 한 감정적 통합이 이루어져야 하는 것이다. 하지만 신애는 그
런 성숙한 단계에 도달하기 위한 뼈아픈 자기성찰의 과정을 과감히 생략한 채 신앙적 이상만을 좇아 과욕을 부린 탓에 더 욱 큰 상처만을 겪었을 뿐이다. 다시 말해서 신애는 사랑과 미움의 공존이 가능한 우울 입장에 도달하지 못하고 마지막 까지 편집성 입장에 머물러 있는 모습을 보인 것이다. Lee (2009)는 원수를 사랑하라는 예수의 요구에 대한 논의에서, 사랑은 미움을 중화시킬 수 있는 능력이 있지만 미움은 사 랑을 증발시켜 버린다는 점에서 사랑의 중요성을 인정하지 만, 모든 고등종교의 본질이 사랑과 자비심에 기초한 이유는 인간의 뿌리 깊은 증오심과 공격성을 물리치기 위한 유일한 수단이 그 방법밖에 없다는 결론에 도달했기 때문으로 보았 다. 따라서 정신분석에서는 분노와 적개심을 중요하게 다루 는 것이며, 그런 점에서 미움을 간과하고 사랑만을 강조하는 것은 너무도 비현실적이라고 하였다. 현대의 종교와 온갖 이 념적 주장들이 간과하고 있는 부분들도 바로 이 점에 있다.

\section{<밀양>의 정신분석}

영화 〈밀양〉의 주제는 정신적 외상을 극복해 가는 과정에 서 신앙적 치유와 정신과적 치료도 중요하지만, 무엇보다 가 치 있는 것은 인간적 교류와 만남에 있는 것이라는 점이다. 사랑하는 가족, 남편과 아들 모두를 잃은 주인공 신애의 정 신적 혼란과 붕괴는 어쩌면 매우 당연한 결과라 할 수 있다. 그녀가 남편의 고향 밀양을 찾아 그곳에 정착한 것은 아무 도 자신을 알아보지 않는 곳이라는 단순한 이유에서였지만, 그러나 다른 한편으로는 남편의 체취와 흔적이 남아 있을 것 이라는 기대와 그것을 공유하고픈 심경도 있었을 것이다. 그 리고 무엇보다 유달리 따스한 밀양의 햇살이 그녀의 어둡고 외로운 마음을 가득 채워줄 것만 같은 바람도 있었을 것이 다. 그곳에서 그녀는 피아노 학원을 운영하며 오로지 아들 준에게 모든 희망과 보람을 찾으며 새로운 삶을 시작한다. 비록 피아니스트로 성공하고픈 자신의 꿈을 이루지는 못했 지만, 그래도 그녀는 순박한 이웃들과의 교류를 통해 외로움 과 아픔을 잊으려 노력한다. 그녀가 이처럼 밀양을 찾은 것 도 어쩌면 애도반응의 일부로 간주할 수 있겠다.

그러나 이웃은 항상 다정한 것이 아니었다. 그중에는 예기 치 못한 악이 숨어 있었기 때문이다. 세속적이라는 측면에서 본다면 모든 등장인물들은 약간씩 악하다고 볼 수도 있다. 그러나 대부분의 경우는 결코 악의가 없는 속성들이다. 이웃 집 여인들의 음담패설이나 커피 배달을 온 다방 레지의 젖 가슴을 훔쳐보는 종찬의 친구들은 오히려 매우 인간적이다. 그러나 신애의 돈을 노리고 그녀의 아들을 유괴하여 살해한 웅변학원 원장은 그처럼 단순한 속물이 아니다. 탐욕에 눈이 먼 악의 화신이기 때문이다. 그러한 악마가 한순간에 하나님 
의 용서를 받고 천사로 둔갑한 현실을 그녀는 도저히 용납 할 수 없었다. 이러한 극적인 반전을 통하여 더욱 빛나는 존 재는 가해자도 피해자도 아닌 오로지 하나님 자신뿐이었다.

따라서 가해자에 대한 신애의 증오심과 복수심은 가식적 인 허울에 불과한 용서라는 단어를 뛰어넘어 하나님과 그 교 회로 향한 것이다. 결국 사랑과 증오심은 동전의 앞뒷면에 불 과하다는 사실이 입증된 셈이다. 증오심을 해결하지 않고 오 로지 사랑만을 외치는 종교적 기만성에 눈이 뜬 신애는 그러 한 증오심을 교회와 신도들에게 분풀이하지만, 결국 그들도 힘없는 약자요 어린 양에 불과하다는 사실을 너무도 잘 알고 있다. 그녀가 더욱 큰 혼란에 빠져 헤어 나오지 못한 것도 그 러한 이율배반적 상황 때문이었다. 하나님의 축복과 용서를 이미 받았다는 살해범의 평온하기 그지없는 얼굴을 뒤로 하 고 교도소를 나온 그녀가 정신을 잃고 쓰러진 것은 당연한 일 이었다. 무어라 형언하기 어려운 삶의 모순에 직면하고 그녀 가 숨을 곳은 의식이 차단된 그녀 자신의 내면세계뿐이었다.

그러나 여기서 우리가 주목할 부분은 따로 있다. 그것은 신애가 결코 완전한 인간이 아니라는 전제조건하에서 논의 할 부분이기도 하다. 우선 신애가 보이는 주된 문제는 평범 한 사람이면 누구라도 드러낼 수 있는 반응이라는 점이다. 그리고 그녀 스스로 도저히 인정하기 어렵고 수용할 수 없는 문제에 대하여 그녀가 취할 수 있는 자기 방어는 주로 부정 과 투사 및 분리, 투사적 동일시, 원시적 이상화, 자기 합리 화, 나르시시즘적 철폐, 행동화 등 매우 미숙한 방어기제에 의존한다는 점이다. 그녀의 방어적 태도는 이미 사건이 발생 하기 이전부터 감지된다. 죽은 남편이 자신을 사랑하지 않고 바람을 피웠다는 사실 자체를 강하게 부정하고 있는 것이다. 또한 신애는 아들의 죽음을 오로지 살인마의 책임 탓으로만 돌릴 뿐이며, 그러한 불공정한 사태가 일어나도록 수수방관 하고서도 직접적인 피해자인 자신을 따돌리고 일방적으로 살해범을 용서해버린 하나님에 대한 원망과 분노를 마치 기 독교 전체가 위선적인 집단인 듯이 일반화시켜 버린다. 그런 점에서 기독교 입장에서는 영화 〈밀양〉에 대하여 매우 서운 한 감정도 들 것이다.

그러나 신앙적 측면뿐 아니라 심리적 측면에서도 신애의 이처럼 미숙한 방어적 태도는 물론 바람직한 것이 아니다. 신 애에게 아쉬운 점은 오로지 선과 악, 옳고 그른 것, 죄와 벌, 심판과 용서라는 이분법적 분리의 관점에 머물고 있다는 점 뿐 아니라, 사건의 발생에 관여되는 직간접적인 요인에 대한 전망을 지니지 못하고 있다는 사실에 있다. 다시 말해서 아들 의 비극적인 죽음에는 신애 자신의 잘못과 실수도 관여되어 있다는 점을 그녀는 인식하지 못하고 있는 것이다. 우선 그녀 는 마치 자신에게 땅에 투자할 돈이 많은 듯이 처신하고 그러
한 소문을 흘린 것이다. 그리고 유괴범이 협박을 가하자 가짜 돈을 준비했다가 다급하게 자신에게 실제로는 돈이 없다고 변명을 늘어놓는다. 그 후 아들은 곧바로 싸늘한 시신으로 변한 것이다. 물론 아들의 유괴로 제 정신이 아닌 상태라는 점을 감안하더라도 그녀에게는 아들의 죽음에 간접적인 책 임이 전혀 없는 것도 아니라는 점이 드러난다.

문제는 신애가 그러한 자책과 후회를 전혀 보이지 않은 채 종교적 위안과 구원만을 바란 태도에 있다. 여기에 그녀 의 함정이 있었다. 비합리적인 이상화와 동일시, 그리고 곧 바로 이어진 과도한 환멸 및 평가절하에서 보듯이 신애의 그러한 다급한 자구책은 그 기초가 매우 허약한 것이었음을 알 수 있다. 충분한 시간적 여유를 갖고 애도과정을 거치면 서 자기 자신에 대한 깊은 내적 성찰이 결여되어 있었던 것 이다. 하나님의 즉각적인 용서와 구원을 받았다고 착각한 점 에서는 신애나 살해범 두 사람 모두 마찬가지라 하겠다. 또 한 피해자인 자신을 제쳐 두고 하나님이 먼저 선수를 쳐서 살인범을 용서했다는 사실에 분노를 터뜨린 신애 역시 매우 피상적인 종교관에 입각한 것이었다. 가해자와 협상하고 용 서하며 보상을 얻는 등의 행위는 세속적인 차원에서 이루어 질 일이다.

신앙적으로 본다면, 심판과 용서란 오로지 하나님에게만 주어진 권능이다. 그러나 신애는 자신에게 용서할 권리가 있 다고 잘못 믿은 것이다. 우선적으로 자신의 과오를 뉘우치고 회개한 연후에 진정으로 하나님의 용서와 구원을 받아 거듭 난 상태였다면, 이미 하나님의 용서를 받았다고 주장하는 죄 인의 말조차 겸허하게 받아들이고 인정해야 하는 것이기 때 문이다. 그러나 신애는 정신병원에서 퇴원한 후에도 미장원 에서 우연히 마주친 살해범의 딸이 눈물을 글썽이며 자신의 머리를 다듬는 행위조차 마음으로 받아들이지 못하고 자리 를 박차고 뛰쳐나가 버린다. 신애의 마음은 마지막 순간까지 용서와 화해 및 수용을 거부하고 있는 모습을 보인다.

Parkes(1972)는 사별의 슬픔에 대한 연구에서 그 단계를 무감각, 충격, 의문, 낙심, 분노, 결단의 단계 등으로 구분 지 었지만, 신애의 경우에는 아직도 분노의 단계에 머물러 있을 뿐, 마지막 결단의 단계에는 이르지 못했음을 알 수 있다. 또 한 Kubler-Ross(1969)가 말한 죽음의 5단계에서 현실의 부 정과 분노에 가득 찬 반문에 이어 세 번째 단계, 즉 협상에 도달해서는 자신에게 주어진 시련과 고통의 배경에 대해 나 름대로의 이유를 생각하면서 스스로를 되돌아보는 자성의 기회를 통하여 자신과의 적절한 타협이 모색되는 것이 상례 인데, 신애는 그러한 과정을 과감히 생략하고 무리한 이상화 를 통해 더욱 높은 단계로 도약하려는 과욕을 부렸기 때문 에 적절한 수용의 단계에 도달하지 못한 것으로 보인다. 
통찰이라는 측면에서 보더라도, 신애는 종교적으로나 심 리적으로 미비한 상태에 있음을 알 수 있다. 그러나 그런 요 구 자체가 무리일 수 있다. 영적으로 또는 심리적으로 그녀 에게는 아직 더 많은 치유의 시간이 요구될 것이기 때문이 다. 따라서 신애에게는 종교 및 정신과적 치료뿐 아니라 상 처와 아픔이 아물기까지 인내심을 유지하며 그녀의 곁을 지 켜 주는 제 3 의 인물이 필요한 것이다. 그런 점에서 신애의 곁을 지키는 수호신은 따로 있었다. 처음부터 끝까지 그녀의 곁을 떠나지 않고 보호하는 종찬의 존재는 정신적으로 만신 창이가 된 신애의 주위를 감싸 주는 따스한 햇살 역할에 충 실했다. 그는 처음에 고장 난 그녀의 차를 수리해 주는 일에 서부터 시작하여 신애가 가는 곳은 어디든 따라다니며 기사 도 정신을 발휘한다. 학원, 거래처, 교회, 살해현장, 장례식 장, 교도소, 정신병원, 미장원 등 그는 신애를 그림자처럼 따 라붙는다. 그러나 그 그림자는 결코 응달진 곳만은 아니다. 오히려 눈부신 햇살의 양지를 가장한 위선보다는 다소 어둡 고 썰렁하더라도 소박하고 순수한 마음이 더욱 소중한 가치 를 지닌다고 영화는 주장하는 듯싶다.

원작 소설에 등장한 남편이 아들과 아내의 비극적인 결말 을 마치 남의 일처럼 무덤덤하게 증언하고 있는 것과는 달 리, 영화 속의 종찬은 고통의 현장에 능동적으로 참여하여 신애를 돕고 보호한다. 비록 그는 우리 주변에서 흔히 볼 수 있는 속물에 불과할지 모르지만, 그래도 마음씨만은 순박하 고 단순하며 따뜻한 정이 있다. 인간은 생각처럼 그렇게 완 전하지도 완벽할 수도 없는 존재다. 그리고 살아가는 목표와 삶의 태도는 주어진 성격과 조건에 따라 저마다 다르다. 종 찬은 그런 점에서 아무런 목표나 이상을 지니고 살아가는 존재는 아니다. 그냥 자신에게 주어진 상황에 열심히 적응하 며 살아가는 존재일 뿐이다. 그러한 태도가 높은 이상을 지 닌 사람들에게는 무가치해 보일지는 모르나 종찬은 자신에 게 주어진 능력의 한계를 인정하고 그 한계 내에서 최선을 다한다는 점에서 비교적 건강한 자아를 지닌 인간이다. 심리 적 균형을 잃고 방황하는 신애에게 지금 그리고 여기에서 가장 절실히 요구되는 인물은 그 어떤 강요나 요구도 없이 그녀의 곁에서 고통과 시련을 함께 나눌 수 있는 바로 그러 한 종찬과 같은 존재라 할 수 있다. 마지막 장면에 이르기까 지 신애의 마음은 여전히 무겁기만 하며, 그녀의 얼굴에는 표정이 없다. 그것은 아직 그녀의 상처가 아물지 못했음을 나타낸다. 누구도 손쉽게 이해할 수 없는 그러한 상처의 치 유에는 그 어떤 무리한 것을 요구함이 없이 단지 그 아픔을 공유하고 이해하고자 애쓰는 마음으로 곁을 지켜주는 자세 가 필요할 것이다.

\section{결 론}

이창동의 영화 〈밀양〉은 이청준의 어둡고 암울한 원작 소 설〈벌레 이야기〉에 비해 그래도 일말의 희망적인 메시지를 전한다. 평범한 소시민의 삶에서 마주치는 예기치 못한 악의 실체와 그에 대한 직면은 어떤 점에서는 불가피한 경우도 많다. 그러나 감당하기 어려운 불행에 처한 힘없는 한 인간 에게 아무런 대안도 없이 무조건 악에 대한 용서와 화해라는 불가능한 사명을 경솔히 떠넘긴다는 것은 매우 무책임한 발 상이다. 인간은 우리가 기대하는 것보다 더 위대할 수도 있 지만 그것은 극소수에 해당할 뿐이며, 대다수의 경우는 불완 전하고 미숙하며 나약하기 그지없다. 더군다나 예기치 못한 비극과 시련에 처할수록 인간은 어린아이처럼 퇴행한다. 따 라서 충분한 애도기간을 통하여 자아기능의 회복이 채 이루 어지지도 못한 상태에서 가해자를 용서한다는 일은 어린아 이에게 무기를 주고 전쟁터로 내보내는 일과 조금도 다를 바 없다. 결국 고통과 사련을 겪고 있는 사람에게 필요한 것 은 공감적 이해와 고통의 공유에 있는 것이지, 부질없는 이상 화에 있는 것이 아니다. 절망의 나락에 빠져든 사람은 물론 자신의 비현실적 도약을 통하여 즉각적으로 고통에서 벗어 날 길을 찾겠지만, 인내심을 지니고 곁을 지켜주는 것이 필 요하다. 따라서 고통받는 사람을 돕는 길도 지혜가 요구되는 것이다. 그런 점에서 자신도 감히 실천하지 못할 악에 대한 용서를 남에게 강요하는 것은 일종의 죄악이다. 영화 〈밀양〉 은 바로 그 점을 강조하고 있다. 그러나 놓치고 있는 점도 있 다. 그것은 너무도 세속적인 관점에서 영적인 구원과 용서의 세계를 다루고 있기 때문이다.

반인륜적 죄악에 대한 용서는 아무나 하는 것이 아니다. 그것은 하나님만의 능력이다. 기독교에서 요구하는 것은 우 선 내 자신안의 죄악을 회개하고 하나님의 용서와 구원을 얻 으면, 원수도 용서하고 사랑하게 될 수 있음을 말하는 것이 지, 무턱대고 원수를 사랑하라는 의미는 아닐 것이다. 악을 악으로 대하는 것 역시 악이다. 그렇다고 반드시 악을 선으 로 대한다고 해서 악에 승리하고 또한 악이 근절되는 것도 아니다. 무엇보다 중요한 것은 악의 실체를 인식하고 스스로 악에 물들지 않도록 자신을 단속하는 일이며, 악에 직접적으 로 대적함으로써 굴복시키려 하거나 용서하기보다는 자기 스스로의 심리적 균형을 잃지 않고 일상성을 유지하는 일이 우선이다. 부정적이든 긍정적이든 만사 제쳐 두고 악에 몰입 하는 것 자체가 이미 악에 물든 징표임을 알아야 한다. 그런 점에서 권선징악 및 약육강식이라는 상호 대립된 개념은 인 간이 만들어 낸 지적 유희의 산물에 지나지 않는다. 진실은 그 중간 어느 타협점에 있을 것이다. 그리고 무엇보다 중요 
한 일은 우리 자신의 내면에 간직된 사랑과 미움의 실체를

깨닫고 더욱 성숙한 단계로의 통합을 이룩함으로써 마음의 평정에 도달하는 것이다.

\section{Conflicts of Interest}

The author has no financial conflicts of interest.

\section{REFERENCES}

Alford CF. What evil means to us. Ithaca: Cornell University Press;1997.

Baumeister RF. Evil: inside human violence and cruelty. New York: Henry Holt and Company; 1999.

Becker E. Escape from evil. New York: Simon \& Schuster;1985.

Berke JH. The wellsprings of fascism: individual malice, group hatreds, and the emergence of national narcissism. Free Assoc 1996;6:334350.

Bose J. Trauma, depression, and mourning. Contemp Psychoanal 1995; 31:399-407.

Bowlby J. Processes of mourning. Int J Psychoanal 1961;42:317-340.

Buber M. Good and evil. Upper saddle River, NJ: Prentice Hall;1980.

Burch B. Mourning and failure to mourn: an object-relations view. Contemp Psychoanal 1989;25:608-623.

Freud S. Beyond the pleasure principle. SE 18. London: Hogarth Press; 1920. p.1-64.

Freud S. Mourning and melancholia. SE 14. London: Hogarth Press; 1917. p.243-358

Grand S. The reproduction of evil: a clinical and cultural perpsective. Hillsdale, NJ: Analytic Press;2000.

Kim HN. Loss and mourning: letting go and mental development. J Ko- rean Psychoanal Soc 2005;16:142-156.

Klein M. Contributions to psychoAnalysis, 1921-1945. New York: McGraw-Hill;1964.

Klein M. Envy and gratitude. In: Khan M. Envy and gratitude, and other works, 1946-1963. London: Hogarth Press;1975. p.176-235.

Kris AO. The lure of hypocrisy. J Am Psychoanal Assoc 2005;53:7-22.

Kubler-Ross E. On death and dying. New York: Macmillan;1969.

Lansky MR. The impossibility of forgiveness: shame fantasies as instigators of vengefulness in Euripides' Medea. J Am Psychoanal Assoc 2005;53:437-464.

Lee BW. Antisocial society. J Korean Psychoanal Soc 2005;16:67-81.

Lee BW. Psychological insights of Jesus and Freud. Psychoanalysis 2009;20:31-44

Lee MS, Choi HI. The inner world of victims of 'May 18 Gwang-ju Democratic Movement' through the dreams. J Korean Psychoanal Soc 2002;13:153-158.

Miller AG. The social psychology of good and evil. New York: Guilford Press;2005.

Parkes CM. Bereavement; studies of grief in adult life. New York: International Universities Press; 1972.

Peck MS. People of the lie: the hope for healing human evil. New York: Touchstone; 1983.

Pollock GH. On mourning, immortality, and utopia. J Am Psychoanal Assoc 1975;23:334-362.

Taylor R. Good and evil. Amherst, NY: Prometheus Books;1999.

Wolfenstein M. Loss, rage, and repetition. Psychoanal Study Child 1969; 24:432-460.

Yi CJ. A story of a worm. Seoul: Yolimwon;1985.

Zimbardo P. The Lucifer effect: understanding how good people turn evil. New York: Random House;2007. 